\title{
Statistical Approach to the Optimization of Oil Extraction from Beniseed (Sesamum indicum) Oilseeds
}

\author{
Eriola Betiku, Tunde F. Adepoju, Akinbiyi K. Omole and Seyi E. Aluko \\ Biochemical Engineering Laboratory, Department of Chemical Engineering, Obafemi Awolowo University, Ile-Ife 220005, Osun \\ State, Nigeria
}

Received: March 28, 2012 / Published: June 20, 2012.

\begin{abstract}
In this work, solvent extraction of oil from Sesamum indicum (beniseed) was investigated. This process was optimized by applying Box-Behnken design and response surface methodology (RSM). A quadratic model was obtained to predict the oil yield as a function of time, solvent volume and sample weight. Based on the RSM, the optimal condition for the oil extraction was found to be sample weight, $30.05 \mathrm{~g}$; time, $58 \mathrm{~min}$; and solvent volume, $296 \mathrm{~mL}$. The optimized condition was validated with the actual oil yield of $87.79 \%$. Physicochemical properties of the oil showed it to be liquid/golden yellow, specific gravity, 0.88 ; viscosity, $35.08 \mathrm{cP}$; acid value, $0.5 \mathrm{mg} \mathrm{KOH} / \mathrm{g}$ oil; saponification value, $190 \mathrm{mg} \mathrm{KOH} / \mathrm{g}$ oil; iodine value, $108 \mathrm{~g} \mathrm{I}_{2} / 100 \mathrm{~g}$ oil; higher heating value, 40.02 $\mathrm{MJ} / \mathrm{kg}$; and cetane number, 50.7. Fatty acid profile of the oil indicted it is highly unsaturated (73.01\%). Hence, the oil could have important food and industrial applications.
\end{abstract}

Key words: Sesamum indicum, solvent extraction, response surface methodology, fatty acid, physicochemical properties.

\section{Introduction}

Sesamum indicum L. also known as beniseed in Africa, is an important oilseed crop cultivated in many parts of the World. Its seeds compose of 44\%-58\% oil, $18 \%-25 \%$ protein and $13.5 \%$ carbohydrate [1]. Beniseed is used to add texture and flavour to a variety of breads, rolls, cracker and salad dressings. Beniseed oil is odourless and has a pleasant taste. It is used widely as cooking oil and as raw material in the manufacture of paints, black ink, margarine, soap and pharmaceuticals [2]. The best quality of the beniseed oil is comparable to olive oil [3]. Fatty acids compositions of the oil are mostly oleic $(32.7 \%-53.9 \%)$, linoleic (39.3\%-59\%), palmitic $(8.3 \%-10.9 \%)$ and stearic (3.4\%-6.0\%) acids [4]. However, the fatty acid composition of this oil varies considerably among the different varieties worldwide [4].

Several methods exist in oil separation from oilseeds

\footnotetext{
Corresponding author: Eriola Betiku, Ph.D., research fields: oil extraction and biofuel production. E-mail: ebetiku@oauife.edu.ng.
}

and these include pounding the seeds in a wooden mortar, extractions with expeller and solvent extraction method. Domestically, pounding beniseed oilseeds in a wooden mortar and treating the product with hot water is the most widely used but oil produced with this method is usually of a slow process, laborious, low oil yield, the unpleasant odour and bitter taste [5]. Extraction of oil from beniseed oilseed using expeller is not without challenges. The method requires high operating and man-power usage, and the oil obtain is of low value. Extraction with solvent has advantages, which include higher yield and less turbidity as well as relatively low operating cost. Literature materials exist on the use of this method for beniseed oil extraction [6, 7]. Maximum beniseed filtered oil recovery reported was $79.63 \%$ [7]. Oil separation by supercritical $\mathrm{CO}_{2}$ has also been exploited. Döker and co-workers [8] successfully extract beniseed oil using this method. Despite the high purity oil extracted, high operating and investment cost pose a great challenge. Although recovery of beniseed oil using solvent extraction 
method has been reported $[9,10]$ but they were not optimized.

Response Surface Methodology (RSM), a useful optimization tool has been applied in research to study the effect of individual variables and their interactions on response variables. It has been used extensively in the optimization of extractions of edible and non edible oils from different oil sources such as pumpkin, palm oil, silkworm pupae, Hibiscus sabdariffa, among others $[11,12]$. The main advantage of RSM is the ability to reduced number of experimental runs needed to provide sufficient information for statistically acceptable results. Physicochemical properties of oils such as colour, refractive index, acid value, saponification value, iodine value, higher heating value, etc. and other properties, for example, cetane number, API, as well as the fatty acid profile are important quality characteristics use in determining their potential use.

This work focused on oil separation from $S$. indicum oilseeds via application of solvent extraction method. To optimize the extraction conditions for the process, RSM was applied to determine the effects of three factors (sample weight, extraction time and solvent volume) and their reciprocal interactions on the beniseed oil yield. In addition, the quality of oil extracted was evaluated by carrying out physicochemical and fatty acid analysis with a view to determining its potential applications.

\section{Materials and Methods}

\subsection{Materials}

Beniseed samples were collected from Lokoja, Kogi State, Nigeria. Chaffs were separated from the oilseeds by winnowing. The cleaned oilseeds were milled to powder by grinding with a plate machine. All chemicals and reagents used for this extraction work were of analytical grades.

\subsection{Methods}

\subsubsection{Experimental Design}

Box-Behnken experimental design was employed in order to optimize oil extraction from the beniseed. A three-level-three-factor design was applied, which generated 17 experimental runs. This included 6 factorial points, 6 axial points and 5 central points to provide information regarding the interior of the experimental region, making it possible to evaluate the curvature effect. Selected extraction variables for the oil separation from the beniseed samples were sample weight (g), extraction time (min) and solvent volume $(\mathrm{mL})$. The coded independent variables levels are displayed in Table 1 while Table 2 shows the 17 experimental runs generated with the experimental oil yields, the predicted oil yields and the residual values. The effects of unexplained variability in the observed response due to extraneous factors were minimized by randomizing the order of experiments.

Table 1 Variables and their Levels for Box-Behnken design.

\begin{tabular}{lllll}
\hline \multirow{2}{*}{ Variable } & Symbol & \multicolumn{3}{c}{ Coded variable levels } \\
\cline { 3 - 5 } & & -1 & 0 & +1 \\
\hline Sample weight $(\mathrm{g})$ & $\mathrm{X}_{1}$ & 30 & 45 & 60 \\
Extraction time $(\mathrm{min})$ & $\mathrm{X}_{2}$ & 40 & 50 & 60 \\
Solvent volume $(\mathrm{mL})$ & $\mathrm{X}_{3}$ & 200 & 250 & 300 \\
\hline
\end{tabular}

Table 2 Coded variables and data for experimental oil yield, predicted oil yield and residue values.

\begin{tabular}{|c|c|c|c|c|c|c|}
\hline $\begin{array}{l}\text { Std } \\
\text { order }\end{array}$ & $\begin{array}{c}\mathrm{X}_{1} \\
(\mathrm{~g})\end{array}$ & $\begin{array}{l}\mathrm{X}_{2} \\
(\mathrm{~min})\end{array}$ & $\begin{array}{l}\mathrm{X}_{3} \\
(\mathrm{~mL})\end{array}$ & $\begin{array}{l}\text { Experiment } \\
\text { oil yield } \\
(\mathrm{w} / \mathrm{w})\end{array}$ & $\begin{array}{l}\text { tal Predicted } \\
\% \text { oil yield } \% \\
(\mathrm{w} / \mathrm{w})\end{array}$ & $\begin{array}{l}\text { Residual } \\
\text { value \% } \\
(\mathrm{w} / \mathrm{w})\end{array}$ \\
\hline 1 & -1 & -1 & 0 & 39.00 & 38.75 & 0.25 \\
\hline 2 & 1 & -1 & 0 & 26.67 & 26.88 & -0.21 \\
\hline 3 & -1 & 1 & 0 & 52.67 & 52.46 & 0.21 \\
\hline 4 & 1 & 0 & 0 & 30.56 & 30.81 & -0.25 \\
\hline 5 & 1 & 0 & -1 & 25.00 & 25.28 & -0.28 \\
\hline 6 & 1 & 0 & -1 & 30.40 & 30.22 & 0.18 \\
\hline 7 & -1 & 0 & 1 & 86.67 & 86.85 & -0.18 \\
\hline 8 & 1 & -1 & 1 & 48.67 & 48.39 & 0.28 \\
\hline 9 & 0 & 1 & -1 & 28.67 & 28.64 & 0.03 \\
\hline 10 & 0 & -1 & -1 & 25.72 & 25.65 & 0.07 \\
\hline 11 & 0 & 1 & 1 & 56.62 & 56.69 & -0.07 \\
\hline 12 & 0 & 0 & 1 & 77.30 & 77.33 & -0.03 \\
\hline 13 & 0 & 0 & 0 & 51.56 & 51.74 & -0.18 \\
\hline 14 & 0 & 0 & 0 & 51.56 & 51.74 & -0.18 \\
\hline 15 & 0 & 0 & 0 & 52.00 & 51.74 & 0.26 \\
\hline 16 & 0 & 0 & 0 & 52.00 & 51.74 & 0.26 \\
\hline 17 & 0 & 0 & 0 & 51.56 & 51.74 & -0.18 \\
\hline
\end{tabular}




\subsubsection{Oil Extraction Description}

A $500 \mathrm{~mL}$ Soxhlet apparatus and $\mathrm{n}$-hexane as solvent were used for this work. Initially, the apparatus was charged with a known weight of the oilseed powder in a muslin cloth placed in a thimble of the apparatus. A round bottom flask containing known volume of n-hexane was fixed to the end of the apparatus and a condenser was tightly fixed at the bottom end of the extractor. The whole set up was heated up in a heating mantle at a temperature of $70{ }^{\circ} \mathrm{C}$. The excess solvent in the oil was recycled by heating. Quantity of oil extracted was determined gravimetrically. The oil yield was calculated as the ratio of the weight of the extracted oil to the weight of the beniseed powder sample used (Eq. 1). The oil obtained was stored appropriately for further processing.

$$
\% \text { Oil yield }(w / w)=\frac{\text { Weight in gram of extracted oil }}{\text { Weight in gram of powder sample }}
$$

2.2.3 Physicochemical Analysis of the Crude Beniseed Oil

The physicochemical properties of the crude seed oil namely, refractive index, moisture content, relative density, viscosity, acid value, saponification value, peroxide value, specific gravity, \% FFA (oleic) and cetane number were determined by AOAC methods. The higher heating value (HHV) and iodine value were calculated using the methods of Demirbas [13] and Wijs, respectively. API and diesel index were estimated by methods reported by Haldar et al. [14].

2.2.4 Fatty Acid Compositions Analysis of Crude Beniseed Oil

Fatty acid composition of the crude seed oil was determined using gas chromatography (HP 6890 powered with HP ChemStation Rev. A 09.01 (1206) Software). Oil sample $(50 \mathrm{mg})$ was esterified for five minute at $95^{\circ} \mathrm{C}$ with $3.4 \mathrm{~mL}$ of the $0.5 \mathrm{M} \mathrm{KOH}$ in dry methanol. The mixture was neutralized using $0.7 \mathrm{M}$ $\mathrm{HCl}$ and $3 \mathrm{~mL}$ of $14 \%$ boron triflouride in methanol was added. The mixture was heated for $5 \mathrm{~min}$ at the temperature of $90^{\circ} \mathrm{C}$ to achieve complete methylation process. The fatty acids were thrice extracted from the mixture with redistilled n-hexane. The content was concentrated to $1 \mu \mathrm{L}$ for gas chromatography analysis and $1 \mu \mathrm{L}$ was injected into the injection port of GC. The starting and final temperatures of the GC oven were 160 and $220^{\circ} \mathrm{C}$, respectively while the final holding time was $1 \mathrm{~min}$.

\subsection{Statistical Data Analysis}

The data obtained from the oil extraction experiments were analyzed statistically using RSM, so as to fit the quadratic polynomial equation generated by the Design-Expert software version 8.0.3.1 (Stat-Ease Inc., Minneapolis, USA). To correlate the response variable to the independent variables, multiple regressions was used to fit the coefficient of the polynomial model of the response. The quality of the fit of the model was evaluated using test of significance and analysis of variance (ANOVA). The fitted polynomial equation is as follows:

$$
\mathrm{Y}=\mathrm{b}_{0}+\sum_{\mathrm{i}=1}^{\mathrm{k}} \mathrm{b}_{\mathrm{i}} \mathrm{X}_{\mathrm{i}}+\sum_{\mathrm{i}=1}^{\mathrm{k}} \mathrm{b}_{\mathrm{ii}} \mathrm{X}_{\mathrm{i}}^{2}+\sum_{\mathrm{i}<j}^{\mathrm{k}} \mathrm{b}_{\mathrm{ij}} \mathrm{X}_{\mathrm{i}} \mathrm{X}_{\mathrm{j}}+\mathrm{e}
$$

where, $\mathrm{Y}$ is response factor (oil yield), $b_{0}$ is the intercept value, $b_{i}(\mathrm{i}=1,2 \ldots \mathrm{k})$ is the first order model coefficient, $b_{\mathrm{ij}}$ is the interaction effect, and $b_{\mathrm{ii}}$ represents the quadratic coefficients of $\mathrm{X}_{\mathrm{i}}$, and $e$ is the random error.

\section{Results and Discussion}

\subsection{Optimization of Beniseed oil Extraction}

This work investigated the optimization of oil extraction from $S$. indicum oilseeds. The coded variables as well as the experimental and predicted values obtained for the oil extraction are depicted in Table 2 while Table 3 a shows the results of test of significance for every regression coefficient. The results showed that the $P$-values of the model terms were significant, i.e. $P<0.05$. The three linear terms $\left(\mathrm{X}_{1}, \mathrm{X}_{2}, \mathrm{X}_{3}\right)$, the three cross-products $\left(\mathrm{X}_{1} \mathrm{X}_{2}, \mathrm{X}_{1} \mathrm{X}_{3}\right.$, $\left.\mathrm{X}_{2} \mathrm{X}_{3}\right)$ and the three quadratic terms $\left(\mathrm{X}_{1}{ }^{2}, \mathrm{X}_{2}{ }^{2}\right.$ and $\left.\mathrm{X}_{3}{ }^{2}\right)$ were all found to be remarkably significant model terms at $95 \%$ confidence level. Based on the large Fisher F-test ( i.e. F-value) and low corresponding probability values ( $P$-values), all the linear terms have 
very strong effects on the oil yield. But sample weight, $\mathrm{X}_{1}(F$-value $=5,781.95)$ was the most significant model term. In order to minimize error, all the coefficients were considered in the design. The results of the second-order response surface model fitting in the form of ANOVA are shown in Table 3b. The model $F$-value of 5,017.95 with $P<0.0001$ implied a high significance for the regression model [15]. The goodness of fit of the model was checked by the coefficient of determination $\left(\mathrm{R}^{2}\right)$. In this work, the $\mathrm{R}^{2}$ value of 0.9999 indicated the sample variation of $99.99 \%$ for oil extraction was attributed to the independent variables and only $0.01 \%$ of the total variations were not explained by the model. The value of the adjusted determination coefficient (Adj. $\mathrm{R}^{2}$ of 0.9997) was also very high, supporting a high significance of the model [16] and all $P$-values were less than 0.0001 , which suggested the model proved suitable for the adequate representation of the actual relationship among the selected variables. The lack-of-fit term of 0.1920 was not significant relative to the pure error. In this case, a non-significant lack of fit is good. Hence, the model could be used in theoretical prediction of the oil extraction. The final equation in terms of coded variables for the Box-Behnken response surface second-order model is expressed in Eq.3.

$$
\begin{aligned}
Y=51.74+8.38 & X_{1}+4.41 X_{2}+19.93 X_{3} \\
& -2.44 X_{1} X_{2}-10.85 X_{1} X_{3} \\
& +5.91 X_{2} X_{3}-6.95 X_{1}^{2}-7.56 X_{2}^{2} \\
& +2.90 X_{3}^{2}
\end{aligned}
$$

The graphical representations of the regression equation for the optimization of beniseed oil extraction are displayed as 3-D surface plot in Fig. 1 (a-c). Fig. 1a shows the response surface plot representing the effect of extraction time, solvent volume and their reciprocal interaction on oil yield while keeping sample weight constant at zero level. The results showed that high extraction time and high solvent volume favoured oil yield while decreasing both factors led to low oil yield. Solvent volume seemed to have more influence on the oil yield than the
Table 3a Test of significance for every regression coefficient.

\begin{tabular}{llllll}
\hline Source & $\begin{array}{l}\text { Sum of } \\
\text { squares }\end{array}$ & df & $\begin{array}{l}\text { Mean } \\
\text { Square }\end{array}$ & $F$-value & $P$-value \\
\hline $\mathrm{X}_{1}$ & 561.80 & 1 & 561.80 & 5781.95 & $<0.0001$ \\
$\mathrm{X}_{2}$ & 115.67 & 1 & 115.67 & 1602.17 & $<0.0001$ \\
$\mathrm{X}_{3}$ & 3178.84 & 1 & 3178.84 & 32716.33 & $<0.0001$ \\
$\mathrm{X}_{1} \mathrm{X}_{2}$ & 23.91 & 1 & 23.91 & 246.10 & $<0.0001$ \\
$\mathrm{X}_{1} \mathrm{X}_{3}$ & 470.89 & 1 & 470.89 & 4846.36 & $<0.0001$ \\
$\mathrm{X}_{2} \mathrm{X}_{3}$ & 139.59 & 1 & 139.59 & 1436.69 & $<0.0001$ \\
$\mathrm{X}_{1}{ }^{2}$ & 203.48 & 1 & 203.48 & 2094.21 & $<0.0001$ \\
$\mathrm{X}_{2}{ }^{2}$ & 240.60 & 1 & 240.60 & 2476.23 & $<0.0001$ \\
$\mathrm{X}_{3}{ }^{2}$ & 35.43 & 1 & 35.43 & 364.63 & $<0.0001$ \\
\hline
\end{tabular}

Table 3b ANOVA of regression equation.

\begin{tabular}{lrrrrr}
\hline Model & $5,017.95$ & \multicolumn{1}{c}{ 9df } & 557.55 & $5,738.26$ & $<0.0001$ \\
Residual & 0.68 & $7 \mathrm{df}$ & 0.097 & & \\
Lack of & 0.45 & $3 \mathrm{df}$ & 0.15 & 2.57 & 0.1920 \\
Fit & & & & & \\
Pure error & 0.23 & $4 \mathrm{df}$ & 0.058 & & \\
Cor total & $5,018.63$ & $16 \mathrm{df}$ & & & \\
$\mathrm{R}^{2}$ & 0.9999 & & Adj. $\mathrm{R}^{2}$ & 0.9997 & \\
\hline
\end{tabular}

extraction time. The response surface plot representing the effect of extraction time, sample weight and their reciprocal interaction on oil yield while keeping solvent volume constant at zero level is depicted in Fig. $1 \mathrm{~b}$. The combination of low sample weight and high extraction time gave high oil yield. The curvatures nature of the three dimensional surfaces in Fig. $1 \mathrm{~b}$ signifies mutual interaction of sample weight, extraction time and solvent volume. Fig. 1c gives the response surface plot representing the effect of solvent volume, sample weight and their reciprocal interaction on oil yield while extraction time constant at zero level. High oil yield was recorded at the low sample weight and high solvent volume. While low solvent volume interacting with low sample weight did not favour the oil yield. High oil yield was also observed at low sample weight and high solvent volume. Solvent volume appeared to have more influence on the oil yield than the sample weight.

The optimal values of the independent variables selected for the beniseed oil extraction were obtained by solving the regression equation (Eq. (2)) using the Design-Expert software. The optimal condition for this process was established as $\mathrm{X}_{1}=30.05 \mathrm{~g}, \mathrm{X}_{2}=58$ 


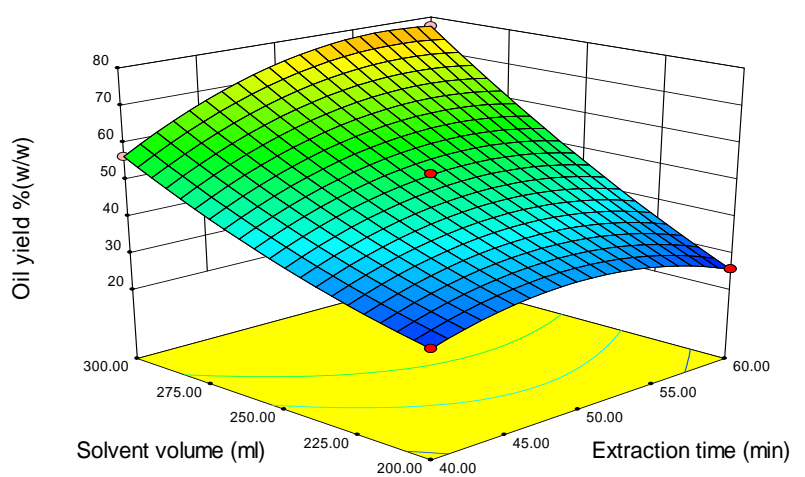

(a)

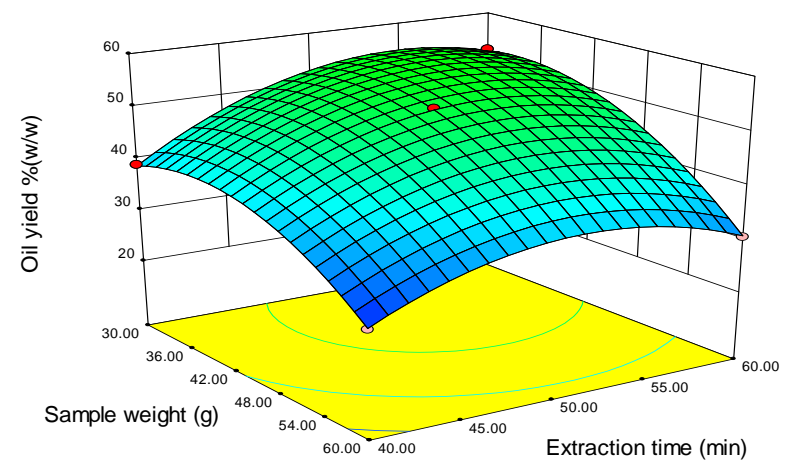

(b)

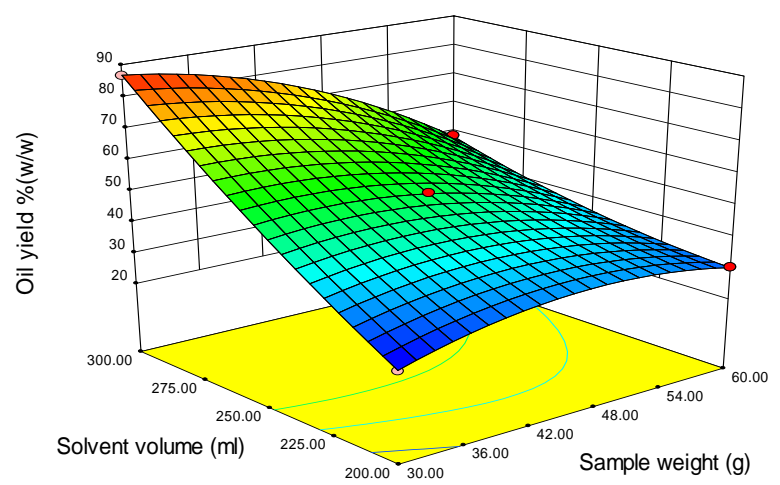

(c)

Fig. 1 Surface plots for beniseed oil extraction.

(a) effect of extraction time, solvent volume and their reciprocal interaction on oil yield.

(b) effect of sample weight, extraction time and their reciprocal interaction on oil yield.

(c) effect of sample weight, solvent volume and their reciprocal interaction on oil yield.

min and $\mathrm{X}_{3}=296 \mathrm{~mL}$. The predicted beniseed oil yield under this optimal condition was $\mathrm{Y}=89.04 \%$ $(w / w)$. Using these optimal condition values for three independent experimental replicates, a mean of $87.79 \%$ (w/w) beniseed oil yield was achieved, which was within the range predicted by the model. It is noteworthy that previously reported yields were below the result obtained in this work.

The results of this work demonstrated that RSM with appropriate experimental design can be effectively applied to the optimization of the process variables in oil extraction from oilseeds. This may provide useful information regarding the development of economic and efficient processes using solvent extraction method.

\subsection{Quality Characterization of the Crude Seed Oil}

\subsubsection{Physical Properties of the Crude Seed Oil}

In order to evaluate the quality of the crude beniseed oil, the content and compositions of the oil was subjected to physicochemical analysis and the results obtained are shown in Table 4. At room temperature, the oil was liquid/golden yellow in colour with refractive index and moisture content of $1.470 \%$ and $0.09 \%$, respectively. Observations on the colour, moisture content and refractive index of the oil agreed with previously published report [10]. Elleuch et al. [17] observed the same value of refractive index for the beniseed oil. The specific gravity of the seed

Table 4 Physicochemical and other characteristics of beniseed oil.

\begin{tabular}{ll}
\hline Parameters & Mean values \\
\hline Physical properties & $\begin{array}{l}\text { Liquid/golden yellow } \\
\text { in colour }\end{array}$ \\
Physical state at $28{ }^{\circ} \mathrm{C}$ & 1.470 \\
Refractive index at $25{ }^{\circ} \mathrm{C}$ & 0.09 \\
Moisture content $(\%)$ & 0.88 \\
Specific gravity & 35.08 \\
Viscosity $(\mathrm{cP})$ at $40{ }^{\circ} \mathrm{C}$ & \\
\hline Chemical properties & 0.25 \\
\%FFA (as oleic acid) & 0.50 \\
Acid value (mg KOH$/ \mathrm{g}$ oil) & 190 \\
Saponification value $(\mathrm{mg} \mathrm{KOH} / \mathrm{g}$ oil) & 108 \\
Iodine value $\left(\mathrm{g} \mathrm{I}_{2} / 100 \mathrm{~g}\right.$ oil) & 7.80 \\
Peroxide value (meq $\mathrm{O}_{2} / \mathrm{kg}$ oil) & 40.02 \\
Higher heating value $(\mathrm{MJ} / \mathrm{kg})$ & \\
\hline Other properties & 50.73 \\
Cetane number & 29.30 \\
API & 55.80 \\
Diesel index & 190.42 \\
Aniline point $\left({ }^{\circ} \mathrm{F}\right)$ & \\
\hline
\end{tabular}


oil was determined as 0.88 and the viscosity, which is a measure of the resistance of oil to shear, was 35.08 cP. Although Besbes et al. [18] reported mean value of 50-100 cP for most vegetable oils, Elleuch et al. [17] reported a lower value $(12.93 \mathrm{cP})$ for beniseed oil, the extraction was carried out at ambient temperature of about $20^{\circ} \mathrm{C}$. This higher value obtained in this present work may be explained by the polymerization and formation of high-molecular-weight compounds [19].

\subsubsection{Chemical Properties of the Crude Seed Oil}

Table 4 contains results obtained for the chemical properties of crude beniseed oil. Low FFA content $(0.25 \%)$ of the seed oil indicated good resistance to hydrolysis. The low acid value $(0.5 \mathrm{mg} \mathrm{KOH} / \mathrm{g}$ oil) of the seed oil showed that it is not only edible but could also have a long shelf life. A high saponification value of 190.00 (mg of $\mathrm{KOH} / \mathrm{g}$ of oil) was obtained for the seed oil, suggesting high concentration of triglycerides. The iodine value of the seed oil was high (108.00 $\mathrm{g}$ of $\mathrm{I}_{2} / 100 \mathrm{~g}$ of oil), which signified the oil contained a substantial level of unsaturation. This observation is supported by the high level of unsaturated fatty acids present in the seed oil [4, 17]. Peroxide value measures the content of hydroperoxides in the oil and its low value indicates high resistance to oxidation. The value obtained for the seed oil in this work was 7.80 milli-equivalent of peroxide/kg of oil, which is within the limit stipulated for vegetable oils. The combination of high iodine value and low peroxide value suggests that the oil could also be stored for a long period without deterioration. These also demonstrate that the oil possesses the desirable qualities of edible oils. The HHV determined for the oil was $40.02 \mathrm{MJ} / \mathrm{kg}$ and it is within the range earlier reported [13] for vegetable oils (37.47-40.62 MJ/kg). The beniseed oil could therefore be used for food purposes and as a feedstock in the industries.

3.2.3 Other Properties of the Crude Seed Oil

Additional fuel properties such as cetane number, API, diesel index and aniline point of the seed oil were determined (Table 4). Cetane number is a measure of the fuel's ignition delay and combustion quality. Standard specification of cetane number for biodiesel is minimum of 40 [20]. The cetane number of the seed oil (50.73) showed that it have high fuel potential. The cetane number reported for most vegetable oils range from 27.6 to $52.9[10,13]$. The API, diesel index and aniline point of the oil were comparable with other vegetable oils as reported previously [14]. The transesterification of the oil may improve its fuel properties.

\subsubsection{Fatty Acid Profile of the Crude Seed Oil}

Gas chromatography analysis of fatty acids present in the seed oil is shown in Table 5. The results indicated that the oil is highly unsaturated. The dominant fatty acids were oleic (43.74\%), linoleic (24.01\%), palmitic (17.8\%) and stearic (7.41\%). The linoleic observed in this work is lower than reported values $[4,17]$. This may be attributed to the variety of the beniseed used. The fatty acid composition of this oil varies considerably among the different varieties worldwide [4]. The total unsaturated fatty acid composition of the oil is $73.01 \%$.

Table 5 Fatty acids compositions of the extracted beniseed oil.

\begin{tabular}{ll}
\hline Fatty acid & Composition \% \\
\hline Myristic acid (C14:0) & 1.11 \\
Palmitic acids (C16:0) & 17.80 \\
Palmitoleic acid (C16:1) & 0.71 \\
Stearic acids (C18:0) & 7.41 \\
Oleic acids (C18:1) & 43.74 \\
Linoleic acids (C18:2) & 24.01 \\
Linolenic acid (C18:3) & 0.51 \\
Arachidic acid (C20:0) & 0.66 \\
Eicosenoic acid (C20:1) & 1.77 \\
Eicosapentaenoic acid (C20:5) & 0.24 \\
Erucic acid (C22:1) & 0.87 \\
Docosahexaenoic acid (C22:6) & 0.15 \\
Nervonic acid (C24:1) & 1.01 \\
SAFA & 26.99 \\
MUFA & 48.10 \\
PUFA & 24.91 \\
\hline
\end{tabular}

SAFA-Saturated fatty acid; MUFAs-Monounsaturated fatty acids, PUFAs-Polyunsaturated fatty acids. 


\section{Conclusions}

This work demonstrated Response Surface Methodology is a good tool for determining the optimal condition for the solvent extraction of oil from Sesamum indicum oilseeds. From the Box Behnken design employed in this work, the maximum seed oil yield of $89.04 \%(\mathrm{w} / \mathrm{w})$ was established at the optimal condition of sample weight of $30.05 \mathrm{~g}$, extraction time of $58 \mathrm{~min}$ and solvent volume of $296 \mathrm{~mL}$. The optimized condition was validated with the actual seed oil yield of $87.79 \%$. The fatty acid profile of the seed oil showed it is highly unsaturated (73.01\%). Physicochemical analysis of the seed oil suggests it could serve as a good candidate for food purposes and as a feedstock in many chemical industries.

\section{Acknowledgments}

Authors wish to thank Dr. T.V. Ojumu of Cape Peninsula University of Technology, South Africa for analytical assistance. E. Betiku gratefully acknowledged equipment donation by the World University Service, Germany and provision of relevant literature by the DAAD.

\section{References}

[1] D. Bedigian, D.S. Seigler, J.R. Harlan, Sesamin, sesamolin and the origin of sesame, Biochemical System Ecology 13 (2) (1985) 133-139.

[2] M. Sangha, P. Gupta, V. Tharpo, Storage studies on plant oils and their methyl esters, Agricultural Engineering International: The CIGR Journal of Scientific Research and Development VI (2004) 1-15.

[3] E.A. Weiss, Oilseed Crop, 2nd ed., Blackwell Longman Group Ltd., USA, 2000, pp. 131-164.

[4] D.M. Yeramanos, S. Hemstreet, W. Saleeb, C.K. Huszar, Oil content and composition of the seed in the world collection of Sesame introductions, Journal of America Oil Chemistry Society 49 (1972) 20-23.

[5] UNIFEM, Oil Extraction, Food Cycle Technology Source Book One, United Nation Industrial Fund for Women Publications, New York, 1987.

[6] T.M.A. Olayanju, Effect of wormshaft speed and moisture content on: The capacity of a beniseed oil expeller, Nigeria Food Journal 11 (2003) 113-116.
[7] T.M.A. Olayanju, R. Akinoso, M.O. Oresanya, Effect of wormshaft speed, moisture content and variety on oil recovery from expelled beniseed, Agricultural Engineering International-The CIGR Journal of Scientific Research and Development, Manuscript FP06 008 VIII (2006) 1-7.

[8] Döker, U. Salgin, N. Yildiz, M. Aydoğmuş, A. Çalimli, Extraction of sesame seed oil using supercritical $\mathrm{CO}_{2}$ and mathematical modelling, Journal of Food Engineering 97 (2010) 360-366.

[9] M.I. Mohammed, Z.U. Hamza, Physicochemical properties of oil extracts from Sesamum indicum L. seeds grown in Jigawa state, Nigeria, Journal of Applied Science and Environmental Management 12 (2) (2008) 99-101.

[10] Njoku, J.A.E. Boniface, N.C. Obitte, D.C. Odimegwu, H.I. Ogbu, Some nutriceutical potential of beniseed oil, International Journal of Applied Resources and Natural Product 2 (4) (2009) 11-19.

[11] P. Mitra, H.S. Ramaswamy, K.S. Chang, Pumpkin (Cucurbita maxima) seed oil extraction using supercritical carbon dioxide and physicochemical properties of the oil, Journal of Food Engineering 95 (2009) 208-213.

[12] C.H. Tan, H.M. Ghazali, A. Kuntom, C.P. Tan, A.A. Ariffin, Extraction and physicochemical properties of low free fatty acid crude palm oil, Food Chemistry 113 (2009) 645-650.

[13] Demirbas, Fuel properties and calculation of higher heating values of vegetable oils, Fuel 7 (1998) 1117-1120.

[14] S.K. Haldar, B.B. Ghosh, A. Nag, Utilization of unattended Putranjiva roxburghii non-edible oil as fuel in diesel engine, Renewable Energy 34 (2009) 343-347.

[15] X. Yuan, J. Liu, G. Zeng, J. Shi, J. Tong, G. Huang, Optimization of conversion of waste rapeseed oil with high FFA to biodiesel using response surface methodology, Renewable Energy 33 (2008) 1678-1684.

[16] A.I. Khuri, J.A. Cornell, Response surfaces: Design and analysis, New York, Marcel Dekker, 1987.

[17] M. Elleuch, S. Besbes, O. Roiseux, C. Blecker, H. Attia, Quality characteristics of sesame seeds and by-products, Food Chemistry 103 (2) (2007) 641-650.

[18] S. Besbes, C. Blecker, C. Deroanne, G. Lognay, N.E. Drira, H. Attia, Heating effects on some quality characteristics of date seed oil, Food Chemistry 91 (2005) 469-476.

[19] M.D. Guillén, A. Ruiz, Formation of hydroperoxy- and hydroxyalkenals during thermal oxidative degradation of sesame oil monitored by proton NMR, Journal of Lipid and Science Technology 106 (2004) 680-687.

[20] M.J. Ramos, C.M. Fernández, A. Casas, L. Rodríguez, A. Pérez, Influence of fatty acid composition of raw materials on biodiesel properties, Bioresource Technology 100 (2009) 261-268. 